\title{
Nickel in Soil Modifies Sensitivity to Diazinon Measured by the Activity of Acetylcholinesterase, Catalase, and Glutathione S-Transferase in Earthworm Eisenia fetida
}

\author{
Agnieszka Zawisza-Raszka and Bogdan Dolezych \\ Department of Animal Physiology and Ecotoxicology, Faculty of Biology and Environmental Protection, \\ University of Silesia, Bankowa 9, 40007 Katowice, Poland \\ Correspondence should be addressed to Bogdan Dolezych; bogdan.dolezych@us.edu.pl
}

Received 16 July 2013; Accepted 24 September 2013

Academic Editor: Yongchao Liang

Copyright (C) 2013 A. Zawisza-Raszka and B. Dolezych. This is an open access article distributed under the Creative Commons Attribution License, which permits unrestricted use, distribution, and reproduction in any medium, provided the original work is properly cited.

Nickel in typical soils is present in a very low concentration, but in the contaminated soils it occurs in locally elevated concentrations. The aim of this study was to examine the effect of nickel in the concentrations of 300 (very high, close to LOEC for reproduction) and 900 (extremely high, close to LOEC for mortality) $\mathrm{mg} / \mathrm{kg}$ dry soil on the life history and acetylcholinesterase, catalase, and glutathione S-transferase activities in earthworm Eisenia fetida and to establish how nickel modifies the sensitivity to organophosphorous pesticide-diazinon. Cocoons production and juveniles' number were significantly lower only in groups exposed to $\mathrm{Ni}$ in the concentration of $900 \mathrm{mg} / \mathrm{kg}$ dry soil for two months. Diazinon administration diminished the AChE activity in the GI tract and in the body wall. The interaction between diazinon and nickel was observed, and, in consequence, the AChE activity after the pesticide treatment was similar to controls in worms preexposed to nickel. Both pesticide administration and exposure to nickel caused an increase in the GST activity in examined organs and CAT activity in body wall. Both biometric and development data and simple enzymatic analysis, especially the AChE and GST, show a Ni pretreatment effect on the subsequent susceptibility to pesticide.

\section{Introduction}

Eisenia fetida is a frequently used earthworm in toxicological and ecotoxicological investigations, since the standardized tests have been launched and commonly approved, and respecting all limits reassumed by Scott-Fordsmand and Weeks [1], Furst [2], and Spurgeon et al. [3], the obtained results may be compared and used as a background in further toxicological experiments. Nickel, generally, is present in soil in very low concentrations, but in some extreme ecosystems, for example, soils contaminated with pig manure [4] and ultramafic soils $[5,6]$, Ni should be treated as a main toxic and life-limiting factor, and its hyperaccumulation in invertebrates inhabiting this milieu is observed [7]. Earthworms are not only the passive subject of exposition to metals in soils, but, being an important component of soil ecosystems, they could play a significant role in further bioavailability and toxicity of metals [8]. Toxicity of nickel to earthworms was studied by Scott-Fordsmand et al. [9]; the authors of a 4-week experiment on Eisenia veneta established some key parameters like "no observable effect concentration" (NOEC), "lowest observable effect concentration" (LOEC), and EC10 and EC50 for mortality and reproduction endpoints. NOEC and LOEC for mortality were established as 700 and $1000 \mathrm{mg} / \mathrm{Ni} \mathrm{kg}$ dry soil, respectively, while for the reproduction were established as 100 and $300 \mathrm{mg} / \mathrm{Ni} \mathrm{kg}$ dry soil, respectively. EC50 for the mortality and reproduction are 684 and $300 \mathrm{mg} \mathrm{Ni} / \mathrm{kg}$ dry soil, respectively. Lock and Janssen [10] reported that changes in mortality of Eisenia fetida exposed to this metal at the concentration of $1000 \mathrm{mg} / \mathrm{kg}$ dry soil for three weeks were not found. The three-weeklong reproductive test was more sensitive, and the cocoons or juveniles production, expressed by their number, was reduced starting from the concentration of $320 \mathrm{mg} \mathrm{Ni} / \mathrm{kg}$ dry soil and 
practically stopped at the concentration of $1000 \mathrm{mg} \mathrm{Ni} / \mathrm{kg}$ dry soil, which was similar to the values reported by ScottFordsmand et al. [9]. Based on the above mentioned data in our work we concentrated on two new aspects of this problem. Firstly, we decided to examine enzymatic and reproductive determinants of the prolonged exposure to nickel and, secondly, to investigate the interaction between $\mathrm{Ni}$ pretreatment and pesticide toxicity, measured by the enzymatic determinants.

We decided to examine the activity of the following three enzymes with established role in biological responses, induced by xenobiotics in earthworms $[11,12]$ : acetylcholinesterase, glutathione S-transferase, and catalase. Esterases are recognized as a good and even predictive biomarker not only in laboratory experiments, but also in real ecosystems investigated by ecotoxicology [13]. Glutathione S-transferase and catalase are enzymes involved in detoxification of various xenobiotic chemicals in earthworms [14] and in free radicals defence, which is important since nickel induces the creation of free radicals [15]. Worms, laboratory rodents, and man have these enzymes in common. Furthermore, worms' response to selenium and nickel is similar to that of laboratory rodents [2].

\section{Materials and Methods}

Experiments were conducted on adult, fully clitellate Eisenia fetida (Savigny) from a laboratory colony, derived from the outdoor culture. Prior to the experiment, the earthworms were maintained for two weeks in uncontaminated medium consisting of commercially available topsoil mixed with Sphagnum peat, to adjust pH $6.0 \pm 0.5$. During the experiment, horse manure collected from a healthy animal that had been grazing uncontaminated field was added once a week to each container to provide food for the earthworms $[3,16]$. Soil moisture was monitored every day using soil humidimeter TFH-100-E (Ebro GmbH, Germany), and it remained at 70\% level. $\mathrm{pH}$ of the soil (measured at the beginning and the end of the experiment) was 5.5-6.5. The chemical characterization of the soil was as follows: nitrogen content $180 \mathrm{mg} / \mathrm{dm}^{3} ; \mathrm{P}_{2} \mathrm{O}_{5}$ content $180 \mathrm{mg} / \mathrm{dm}^{3} ; \mathrm{K}_{2} \mathrm{O}$ content $210 \mathrm{mg} / \mathrm{dm}^{3}$. Mean organic matter content (27\%) and organic carbon content (1.4\%) [17] did not differ statistically during the whole experiment. Covered experimental containers (plastic boxes $20 \times 12 \times 13 \mathrm{~cm}$ ) were maintained in a thermostatic cabinet at $20^{\circ} \mathrm{C}$ in the dark.

To contaminate soil with nickel, solutions of nickel chloride $\left(\mathrm{NiCl}_{2} \cdot 6 \mathrm{H}_{2} \mathrm{O}\right.$, Sigma), was mixed with dry soil to obtain the required water content $(35 \%$ wet weight which gives $70 \%$ moisture) and metal concentrations. The same volume of distilled water was added to controls. Soil with nickel concentrations of 300 or $900 \mathrm{mg} \mathrm{Ni} \mathrm{kg}^{-1}$ dry weight of soil was used in all tests. Six replicates with 13 individuals in each were used for each soil test extended over two months.

All worms were weighed once a week (Metler Toledo AG245), and after that were put back into the same container to continue the soil test. All cocoons were removed, counted, and maintained on wet filter paper until hatching. Both the newly emerged F1 juveniles and laid cocoons were counted twice a week.
After two months, earthworms were transferred for 24 hours into wet filter paper to clean their intestinal tracts, and some of them have undergone the next standard OECD filter paper test [18] to assess the acute toxicity of diazinon. A water solution of diazinon (obtained from Institute of Industrial Organic Chemistry, Poland) of concentration $18,75 \mathrm{mg} / \mathrm{dm}^{3}$ was prepared, and $1 \mathrm{~mL}$ of this solution was used per each chamber. Each individual was exposed to $53,6 \mu \mathrm{g}$ of active compound $/ \mathrm{g}$ of the body weight (b.w.) for one hour. There were ten replicates of the test.

Both the treatments produced the following experimental groups:

(1) $\mathrm{K}$, the control group;

(2) Ni300 group, exposed to nickel in the concentration of $300 \mathrm{mg} / \mathrm{kg}$ dry soil for two months;

(3) Ni900 group, exposed to nickel in the concentration of $900 \mathrm{mg} / \mathrm{kg}$ dry soil for two months;

(4) P group, exposed to diazinon in a dose of $53,6 \mu \mathrm{g}$ of active compound $/ \mathrm{g}$ b.w. for 1 hour in the acute test;

(5) Ni300P group, preexposed to nickel in the concentration of $300 \mathrm{mg} / \mathrm{kg}$ dry soil for two months and then exposed to diazinon in a dose of $53,6 \mu \mathrm{g}$ of active compound $/ \mathrm{g}$ b.w. for 1 hour in the acute test;

(6) Ni900P group, preexposed to nickel in the concentration of $900 \mathrm{mg} / \mathrm{kg}$ dry soil for two months and then exposed to diazinon in a dose of $53,6 \mu \mathrm{g}$ of active compound $/ \mathrm{g}$ b.w. for 1 hour in the acute test.

The nickel content in earthworms was analysed using AAS method (Unicam 939 SOLAAR, equipped with a graphite furnace). Dried samples were mineralized using $65 \%$ ultrapure $\mathrm{HNO}_{3}$ (Merck). Using the same method, Ni content was measured in the dry soil samples, in the fraction obtained by prerinsing with $2 \mathrm{~N} \mathrm{HNO}_{3}$, according to Houba et al. [19]. The bioaccumulation coefficient was obtained dividing the $\mathrm{Ni}$ concentration in the body by its concentration in the soil [20].

Obtained from prepared on ice earthworm body walls and gastrointestinal tracts were homogenized in ice cold $0.05 \mathrm{M}$ phosphate buffer (adjusted to $\mathrm{pH}$ 7.4) using a glassTeflon homogenizer, and then deeply frozen $\left(-80^{\circ} \mathrm{C}\right)$. Adequate number of samples was defrosted on ice for further biochemical analysis done with the use of a Cecil spectrophotometer.

The acetylcholinesterase (AChE) activity was determined using the combined methods described by Scaps et al. [21] and Dauberschmidt et al. [22], adapted to earthworms. The principle of this method is the hydrolysis of acetylthiocholine iodide by AChE, and spectrophotometrical detection $(410 \mathrm{~nm})$ of the yellow product of the reaction of acetylthiocholine with DTNB in adequate milieu. Activity is expressed as nmol acetylthiocholine $\mathrm{min}^{-1} \mathrm{mg}^{-1}$ protein.

The catalase (CAT) activity was determined by monitoring the UV radiation absorbance by hydrogen peroxide at $230 \mathrm{~nm}$ in $50 \mathrm{mM}$ phosphate buffer adjusted to $\mathrm{pH} 7.0$ [23]. The specific activity unit was defined as the enzyme equivalent reducing $1 \mathrm{mmol} \mathrm{H}_{2} \mathrm{O}_{2} \mathrm{~min}^{-1} \mathrm{mg}^{-1}$ protein. 
TABLE 1: Nickel concentration ( $\mathrm{mg} * \mathrm{~kg}^{-1}$ of the dry sample) in soil and Eisenia fetida exposed to nickel. Bioaccumulation factor (BAF) was calculated from the obtained experimental values. Ni concentration in control conditions (K) was below the threshold of determination (btd).

\begin{tabular}{lcccc}
\hline Experimental group & $\begin{array}{c}\text { Gastrointestinal } \\
\text { tract }\end{array}$ & Body wall & Whole body & Soil \\
\hline & Mean \pm SD $(n)$ & Mean \pm SD $(n)$ & Mean \pm SD $(n)$ & Mean \pm SD $(n)$ \\
K & $\operatorname{btd}(6)$ & btd $(13)$ & btd $(16)$ & btd $(4)$ \\
Ni300 & $3,07 \pm 0,78(9)$ & $0,66 \pm 0,14(12)$ & $3,27 \pm 0,12(11)$ & $265,38 \pm 10,78(4)$ \\
& BAF $=0,012$ & BAF $=0,002$ & BAF $=0,012$ & \\
Ni900 & $14,95 \pm 2,02^{*}(9)$ & $2,48 \pm 0,39^{*}(12)$ & $5,12 \pm 0,48(12)$ & $857,57 \pm 10,18(4)$ \\
& BAF $=0,017$ & BAF $=0,003$ & BAF $=0,006$ & \\
\hline
\end{tabular}

Abbreviations are explained in Section 2. Asterisk * indicates the statistically significant differences between Ni300 and Ni900 groups in the analysed organs.

TABLE 2: Acetylcholinesterase (AChE) activity (nmol hydrolysed acetylthiocholine iodide $* \mathrm{~min}^{-1} * \mathrm{mg}^{-1}$ protein), S-glutathione transferase (GST) activity ( $\mu \mathrm{mol} \mathrm{CDNB} * \mathrm{~min}^{-1} * \mathrm{mg}^{-1}$ protein), and catalase (CAT) activity (mmol decomposed $\mathrm{H}_{2} \mathrm{O}_{2} * \mathrm{~min}^{-1} * \mathrm{mg}^{-1}$ protein) in the intestinal tract and body wall of Eisenia fetida exposed to nickel (Ni groups), pesticide (P group), and nickel and pesticide administered jointly (NiP group).

\begin{tabular}{|c|c|c|c|c|c|c|}
\hline \multirow{3}{*}{ Group } & \multicolumn{2}{|c|}{$\mathrm{AChE}$} & \multicolumn{2}{|c|}{ GST } & \multicolumn{2}{|c|}{ CAT } \\
\hline & Gastrointestinal tract & Body wall & Gastrointestinal tract & Body wall & Gastrointestinal tract & Body wall \\
\hline & Mean \pm SD $(n)$ & Mean $\pm \operatorname{SD}(n)$ & Mean $\pm \operatorname{SD}(n)$ & Mean \pm SD $(n)$ & Mean \pm SD $(n)$ & Mean $\pm \operatorname{SD}(n)$ \\
\hline K & $149,44 \pm 12,59^{\mathrm{bc}}(6)$ & $130,09 \pm 11,21^{\mathrm{abc}}(7)$ & $0,025 \pm 0,004^{\mathrm{a}}(7)$ & $0,022 \pm 0,003^{\mathrm{a}}(8)$ & $0,085 \pm 0,019^{b c}(7)$ & $0,019 \pm 0,002^{\mathrm{a} *}(7)$ \\
\hline $\mathrm{P}$ & $70,61 \pm 9,59^{a}(6)$ & $80,59 \pm 8,59^{a}(6)$ & $0,042 \pm 0,005^{\mathrm{a}}(9)$ & $0,031 \pm 0,005^{\mathrm{abc} *}(6)$ & $0,074 \pm 0,020^{\mathrm{ab}}(8)$ & $0,048 \pm 0,011^{\mathrm{c*}}(8)$ \\
\hline $\mathrm{Ni} 300$ & $162,35 \pm 22,99^{b c}(7)$ & $152,44 \pm 24,17^{\mathrm{bc}}(5)$ & $0,059 \pm 0,006^{\mathrm{ab}}(6)$ & $0,024 \pm 0,004^{\mathrm{ab} *}(6)$ & $0,039 \pm 0,008^{\mathrm{a}}(6)$ & $0,024 \pm 0,003^{\mathrm{ab} *}(5)$ \\
\hline Ni300P & $133,04 \pm 19,51^{\mathrm{abc}}(7)$ & $111,24 \pm 14,33^{\mathrm{ab}}(5)$ & $0,084 \pm 0,007^{\mathrm{b}}(5)$ & $0,035 \pm 0,006^{\mathrm{c*}}(5)$ & $0,083 \pm 0,011^{b c}(6)$ & $0,040 \pm 0,008^{\mathrm{c} *}(7)$ \\
\hline Ni900 & $179,82 \pm 29,19^{c}(6)$ & $183,26 \pm 30,76^{\mathrm{c}}(7)$ & $0,078 \pm 0,010^{\mathrm{b}}(7)$ & $0,032 \pm 0,005^{\mathrm{bc} *}(4)$ & $0,076 \pm 0,023^{\mathrm{ab}}(7)$ & $0,031 \pm 0,005^{\mathrm{abc} *}(6)$ \\
\hline Ni900P & $124,07 \pm 9,83^{\mathrm{ab}}(5)$ & $151,87 \pm 18,50^{\mathrm{bc} *}(5)$ & $0,087 \pm 0,019^{\mathrm{b}}(6)$ & $0,048 \pm 0,011^{\mathrm{c*}}(5)$ & $0,131 \pm 0,028^{\mathrm{c}}(6)$ & $0,037 \pm 0,007^{\mathrm{bc*}}$ \\
\hline
\end{tabular}

Abbreviations are explained in Section 2. The same superscript letters show the homogeneity of compared groups (in columns), according to the ANOVA statistics. Asterisk ${ }^{*}$ indicates the statistically significant difference between intestinal tract and body wall.

The glutathione S-transferase (GST) activity was determined by modification to suit earthworms procedure of Yu [24] with CDNB (1-chloro-2,4-dinitrobenzene) as a substrate. The conjugation of CDNB to glutathione results in the product measured spectrophotometrically at $340 \mathrm{~nm}$. Activity is expressed as $\mu \mathrm{mol} \mathrm{GSH}$ conjugated $\mathrm{min}^{-1} \mathrm{mg}^{-1}$ protein.

Protein content was determined using the Bradford method [25].

Data were analysed by ANOVA (Statistica 5.1 software) to determine the effect of nickel and pesticide on enzyme activities. Significant treatment effects $(P \leq 0.05)$ were investigated using nonparametric post hoc tests.

\section{Results}

Nickel concentration in control soil was well below the threshold of detection. The nominal concentrations 300 and $900 \mathrm{mg} \mathrm{Ni} / \mathrm{kg}$ in the soil tests were similar to the real concentrations, determined in samples collected after two months of test duration (Table 1).

Nickel concentration in Eisenia depended on the concentration of $\mathrm{Ni}$ in soil, but the differences between experimental groups were stronger expressed in concentrations of nickel in intestinal tracts of earthworms compared with their whole body.

Bioaccumulation factor (BAF) depending on the organ and calculated for the whole body was twofold smaller in case of group Ni900 when compared with Ni300 group.
Body mass of earthworms did not differ between groups (Figure 1), and at the end of test, it was similar to the initial body mass. Exposure to nickel did not affect this parameter.

Cocoons production and the number of juveniles were significantly lower only in groups exposed to $900 \mathrm{mg} \mathrm{Ni} / \mathrm{kg}$ dry soil (Figures 2 and 3), but in the last week of experiment, the number of juveniles compared with controls was smaller also in earthworms exposed to $300 \mathrm{mg} \mathrm{Ni} / \mathrm{kg}$ dry soil.

Diazinon administration diminished the AChE activity in the GI tract (by 50\%) and in the body wall (by $40 \%$ ). In nickel treated worms, the AChE activity was increased-even by $40 \%$ in the body wall of Eisenia inhabiting soil with the higher Ni content. The antagonistic effect between diazinon and nickel was observed, and, in consequence, the AChE activity after the pesticide treatment was similar to controls in worms preexposed to nickel via soil (Table 2).

The pattern of GST activity was completely different. Both pesticide administration and exposure to nickel caused an increase in the GST activity in examined organs of earthworms. Additive action of both factors was expressed in the highest GST activity in Ni900P group (Table 2).

The CAT activity was elevated in the body walls of Eisenia fetida. This effect was observed in worms in all examined groups, except for Ni300 group. In the gastrointestinal tract (GI), an increase in catalase activity was observed only in worms from Ni900P group, while in Eisenia treated with the lower $\mathrm{Ni}$ content, the activity of this enzyme was diminished (Table 2). 


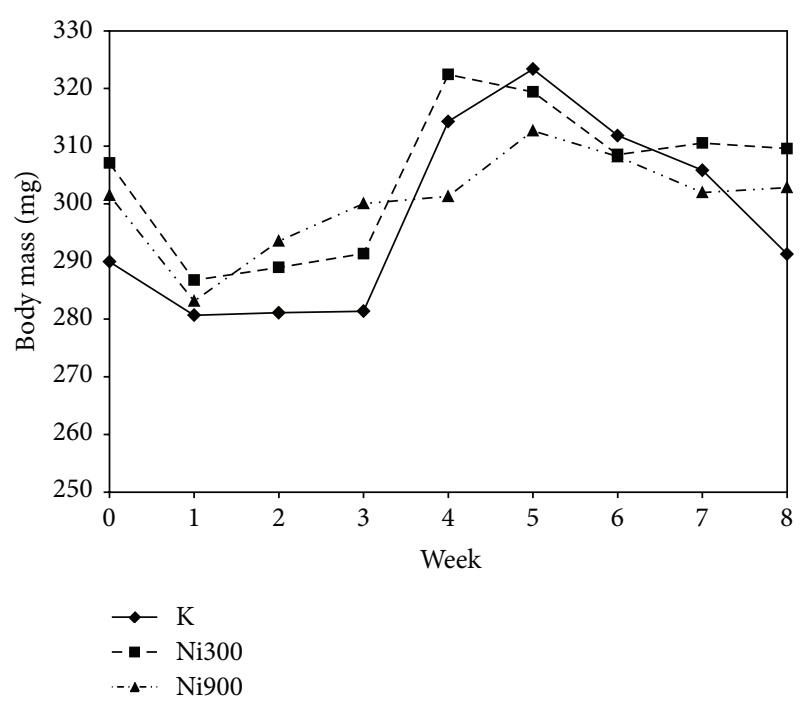

FIGURE 1: Changes of the body mass of Eisenia fetida during the soil test.

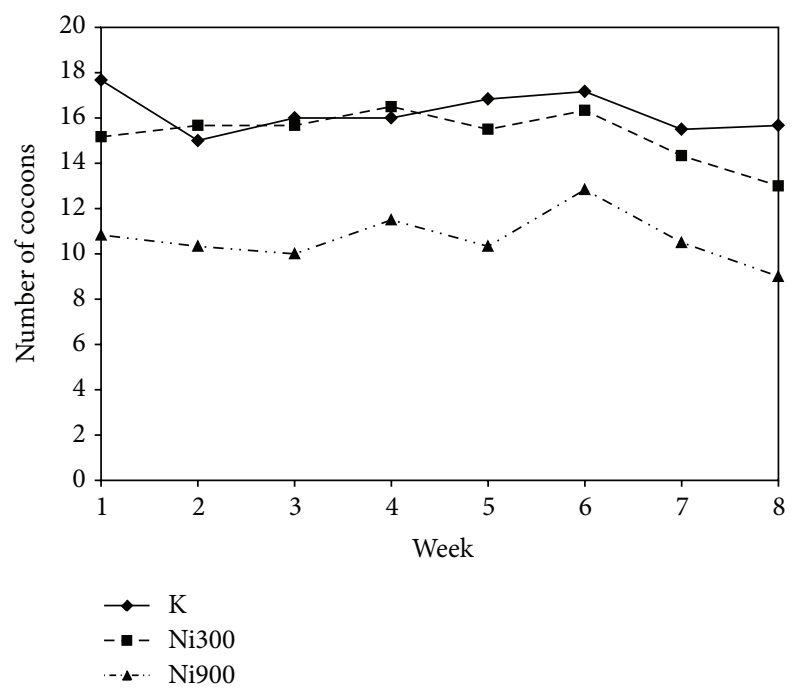

FIGURE 2: Mean number of cocoons produced by earthworms from experimental groups. Values for Ni900 significantly differ from those of $\mathrm{K}$ and Ni300 (post hoc Kruskal-Wallis test; $P \leq 0.05$ ).

\section{Discussion}

Our tests were extended over 8 weeks, and comparing with effects obtained by Scott-Fordsmand et al. [9] and Lock and Janssen [10], in three-week-long tests and four-weeklong tests, respectively, we found similar results-the concentrations of 300 and $900 \mathrm{mg} \mathrm{Ni} / \mathrm{kg}$ dry soil did not affect the Eisenia body mass. Apparently, adult earthworms have a strong tolerance to Ni concentrations. High tolerance was revealed in case of E. fetida exposed to chromium, copper, and arsenic in soil. It was stated that being under metal stress, E. fetida can allocate more energy to growth than reproduction [26]. We cannot exclude that such reaction occurred in our experiment. After 8 weeks of exposure

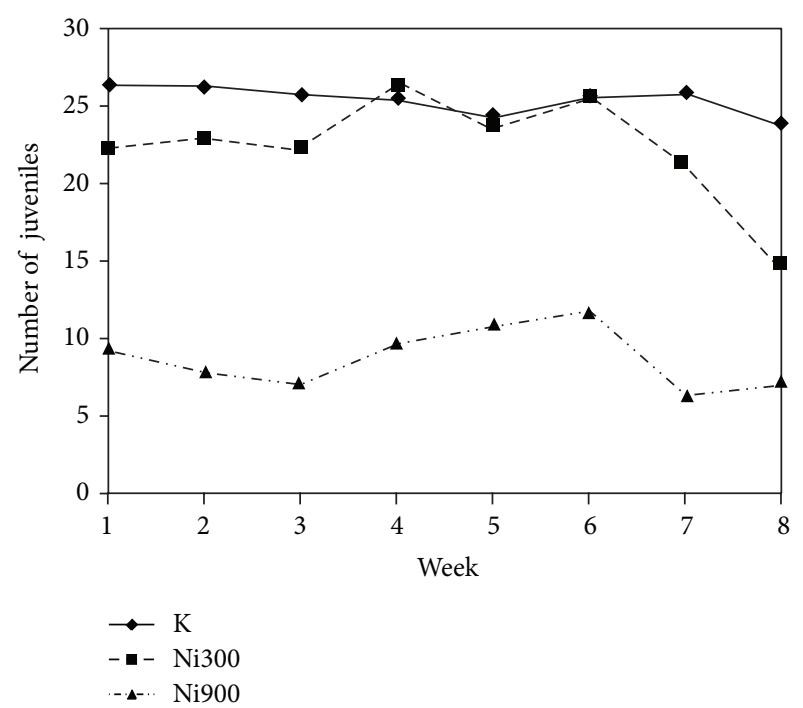

FIGURE 3: Mean number of hatched earthworms in experimental groups. Values for Ni900 and for Ni300 at the 8th week significantly differ from those of $\mathrm{K}$ and $\mathrm{Ni}_{300_{1-7} \text { weeks }}$ (post hoc Kruskal-Wallis; test $P \leq 0.05)$.

to 300 and $900 \mathrm{mg} \mathrm{Ni} / \mathrm{kg}$, no significant effect on growth and survival of adult E. fetida was revealed, suggesting that "lowest observable effect level" (LOEL) of Ni on survival and body mass can be above $900 \mathrm{mg} \mathrm{Ni} / \mathrm{kg}$ level.

Cocoons production and the number of juveniles were significantly smaller only in groups exposed to the highest $\mathrm{Ni}$ content. Furthermore, we found that in the last, eighth, week of experiment, the number of juveniles was also smaller in earthworms exposed to $\mathrm{Ni}$ in a concentration of $300 \mathrm{mg} / \mathrm{kg}$. Probably, in the case of group Ni900 during the whole experiment and for Ni300 at the end, the cost of adaptation to $\mathrm{Ni}$ in soil was too high, and earthworms were not able to allocate the sufficient energy for reproductive processes, because there is a competition in energy allocation, well described by Jager et al. [27]. This difference between the results of the simple toxicity test and the reproductive test was reported also by Lock and Janssen [10] and Scott-Fordsmand et al. [9], who observed that NOEC, LOEC, and EC10 and EC50 for the neutral red retention time were closer to the values established for reproduction, instead of these concerning mortality. It could be explained bearing in mind the fact that nickel is recognized not only as a pollutant, but also as a minor essential element in invertebrates [28], so the homeostatic mechanisms of metals turnover can modify its toxicity and also can complicate its kinetics, which was described as less clear when compared with $\mathrm{Cd}, \mathrm{Zn}$, and $\mathrm{Cu}$ and as difficult to quantitative comparisons [29]. The real concentration of nickel in body organs depends on its bioavailability, uptake, distribution, and elimination processes. In our study, we observed that the intestinal tract was the first organ that reflected the elevation of $\mathrm{Ni}$ concentration in soil, while the reaction of the whole body manifested by accumulation of $\mathrm{Ni}$ was about twofold weaker. Barrera et al. [20] showed that Ni concentration in the earthworm egesta was higher than that in the bulk soil. 
For use in our tests relatively high concentrations of nickel were chosen based on the range of $\mathrm{Ni}$ concentrations used by Scott-Fordsmand et al. [9] and Lock and Janssen [10]. The concentration of $300 \mathrm{mg} \mathrm{Ni} / \mathrm{kg}$ dry soil, in our protocol the lowest concentration, was, in fact, very high, close to LOEC for reproduction, but, regarding the NOEC established at $100 \mathrm{mg} \mathrm{Ni} / \mathrm{kg}$ dry soil [9], it was an effective concentration. Furthermore, these concentrations are similar to the field condition in some specific ultramafic ecosystems [6].

The biochemical and physiological approach in earthworms toxicology, according to review of Spurgeon et al., [3] needs the determination of supplementary bioindices, correlated with the above-described biometric and toxicological data. One of them is neutral red retention time [1], used also in studies concerning Ni toxicity [9]. We decided to examine the activity of acetylcholinesterase, glutathione S-transferase, and catalase. Nickel itself, especially in the highest concentration, in our experiments augmented the activity of all examined enzymes. This suggests that AChE, GST, and CAT are involved in the body's response to elevated $\mathrm{Ni}$ concentration, both CAT and GST directly as a part of the defence mechanisms against free radicals, and AChE as a marker of general activation, and in this way modifying behavioural reactions of worms. The reaction of earthworm AChE to heavy metals is difficult to predict, in some cases inhibition of AChE is observed [30], but on the other hand Scaps et al. [21] did not find any impact of cadmium and lead on AChE activity in eight-week-long experiment.

We studied also the effect of nickel pretreatment on the toxicity of common pesticide diazinon. AChE is sensitive to organophosphorous pesticides, and their inhibitory effect may be maintained for months [31]. Pesticide in the nonpretreated worms acted as we expected [1,11]; a significant decrease in the activity of $\mathrm{AChE}$ and a simultaneous increase in the GST activity were observed. But there was a significant impact of nickel pretreatment on the activity of the abovementioned enzymes. In the Ni pretreated worms, diazinon did not decrease AChE activity, while in case of the GST activity pesticide acted stronger in pretreated than in the nonpretreated worms. In the case of CAT activity, only pretreatment with the highest dose of $\mathrm{Ni}$ resulted in the significant activity increase. This confirms that the interaction between metals and pesticides is complex, as it was described, for example, by Jonker et al. [32] where both synergistic and antagonistic effects of carbendazim and copper on reproduction were observed. The mechanism of the abovementioned interaction is still not clear, but metallothioneins could be the possible junction between both, metal and pesticide intoxications [33].

Based on the NOEC, LOEC, and EC10 and EC50 established by Scott-Fordsmand et al. [9], we decided to use only two $\mathrm{Ni}$ concentrations, because the main aim of our work was to examine enzymatic indices and the effect of Ni pretreatment on diazinon susceptibility in worms in two extremes, but possible conditions. Certainly all the limits associated with the extrapolation of obtained data into the real field conditions $[13,34,35]$, as well as additional crossreactions occurring in soil [36], should be taken into consideration. Obtained biometric and development data and simple enzymatic analysis, especially the activity of $\mathrm{AChE}$ and GST, allowed us to find a Ni pretreatment effect on the susceptibility to pesticide, in spite of the fact that Eisenia fetida is the least sensitive species to insecticides, including diazinon [36, 37]. Further studies should also include the pesticide impact on reproductive abilities in Eisenia, because pesticides, in spite of their acute toxicity, manifested also this kind of action [38, 39].

For a similar phenomenon, using the same nickel concentrations and similar protocol of intoxication, we observed and described, in different invertebrates, an insect Spodoptera exigua [40], where nickel pretreatment changed the response to pesticide, but in multidirectional way, depending on enzyme and organ, and in a land snail, we observed and discussed Helix aspersa [41], where nickel pretreatment augmented the response to a single diazinon application, especially AChE activity, which was greatly reduced compared with nickel-untreated snails. These results show that nickel itself and nickel pretreatment provoke species-dependent biochemical responses and augment the earthworms susceptibility to pesticide.

\section{Conclusions}

(1) Nickel in soil influenced Eisenia fetida reproduction, and its toxicity was the highest at the concentration of $900 \mathrm{mg} / \mathrm{kg}$ dry soil. In this concentration, close to LOEC for mortality and slightly exceeded EC50, bioaccumulation factor (BAF) calculated for the whole body was twofold lower when compare with $300 \mathrm{mg} \mathrm{Ni}$, and cocoons production and the number of juveniles were significantly lower when compared with other groups. Concentration of $300 \mathrm{mg} \mathrm{Ni} / \mathrm{kg}$ dry soil probably does not exceed the adaptation range of this earthworm.

(2) Pesticide diazinon and nickel administered separately disturbed the acetylcholinesterase activity in an opposite way: diazinon administration diminished the AChE activity in the gastrointestinal tract and in the body wall, while in nickel treated worms the AChE activity was increased. The interaction between diazinon and nickel was observed, and, in consequence, the AChE activity after the pesticide treatment was similar to controls in worms preexposed to nickel.

(3) Both pesticide administration and exposure to nickel caused an increase in the GST activity in examined organs of earthworms. The CAT activity generally was elevated in the body walls of Eisenia fetida.

(4) Regarding all examined biometric and development data and simple enzymatic analysis, we can recommend using in similar experiments AChE and GST activities as susceptible tool to measure metalpesticide interactions.

\section{Conflict of Interests}

The authors declare that there is no conflict of interests regarding the publication of this paper. 


\section{Acknowledgment}

This work was granted by the University of Silesia, Katowice, Poland.

\section{References}

[1] J. J. Scott-Fordsmand and J. M. Weeks, "Biomarkers in earthworms," Reviews of Environmental Contamination and Toxicology, vol. 165, pp. 117-159, 2000.

[2] A. Furst, "My saga with earthworms," Food and Chemical Toxicology, vol. 40, no. 6, pp. 789-791, 2002.

[3] D. J. Spurgeon, J. M. Weeks, and C. A. M. van Gestel, "A summary of eleven years progress in earthworm ecotoxicology," Pedobiologia, vol. 47, no. 5-6, pp. 588-606, 2003.

[4] J. Bak, J. Jensen, M. M. Larsen, G. Pritzl, and J. Scott-Fordsmand, "A heavy metal monitoring-programme in Denmark," Science of the Total Environment, vol. 207, no. 2-3, pp. 179-186, 1997.

[5] R. D. Reeves and A. J. M. Baker, "Metal-accumulating plants", in Phytoremediation of Toxic Metals: Using Plants to Clean Up the Environment, I. Raskin and B. D. Ensley, Eds., pp. 139-229, John Wiley \& Sons, New York, NY, USA, 2000.

[6] C. Sirguey, S. Masoura, C. Schwartz, G. Echevarria, and J. L. Morel, "Phytoextraction and bioavailability of $\mathrm{Cd}$ and $\mathrm{Ni}$ in soils," in Ultramafic Rocks: Their Soils, Vegetation and Fauna. Proceedings of the Fourth International Conference on Serpentine Ecology, R. S. Boyd, A. J. M. Baker, and J. Proctor, Eds., pp. 305310, Science Reviews, St Albans, UK, 2003.

[7] M. Augustyniak, J. Mesjasz-Przybylowicz, M. Nakonieczny, M. Dybowska, W. Przybylowicz, and P. Migula, "Food relations between Chrysolina pardalina and Berkheya coddii, a nickel hyperaccumulator from South African ultramafic outcrops," Fresenius Environmental Bulletin, vol. 11, no. 2, pp. 85-90, 2002.

[8] M. I. Zorn, C. A. M. van Gestel, and H. Eijsackers, "The effect of Lumbricus rubellus and Lumbricus terrestris on zinc distribution and availability in artificial soil columns," Biology and Fertility of Soils, vol. 41, no. 3, pp. 212-215, 2005.

[9] J. J. Scott-Fordsmand, J. M. Weeks, and S. P. Hopkin, "Toxicity of nickel to the earthworm and the applicability of the neutral red retention assay," Ecotoxicology, vol. 7, no. 5, pp. 291-295, 1998.

[10] K. Lock and C. R. Janssen, "Ecotoxicity of nickel to Eisenia fetida, Enchytraeus albidus and Folsomia candida," Chemosphere, vol. 46, no. 2, pp. 197-200, 2002.

[11] A. Dhainaut and P. Scaps, "Immune defense and biological responses induced by toxics in Annelida," Canadian Journal of Zoology, vol. 79, no. 2, pp. 233-253, 2001.

[12] P. Łaszczyca, M. Augustyniak, A. Babczyńska et al., "Profiles of enzymatic activity in earthworms from zinc, lead and cadmium polluted areas near Olkusz (Poland)," Environment International, vol. 30, no. 7, pp. 901-910, 2004.

[13] J. M. Weeks, D. J. Spurgeon, C. Svendsen et al., "Critical analysis of soil invertebrate biomarkers: a field case study in Avonmouth, UK," Ecotoxicology, vol. 13, no. 8, pp. 817-822, 2004.

[14] L. H. Booth, V. Heppelthwaite, and A. McGlinchy, "The effect of environmental parameters on growth, cholinesterase activity and glutathione S-transferase activity in the earthworm (Apporectodea caliginosa)," Biomarkers, vol. 5, no. 1, pp. 46-55, 2000.

[15] E. L. B. Novelli, N. L. Rodrigues, and B. O. Ribas, "Superoxide radical and toxicity of environmental nickel exposure," Human and Experimental Toxicology, vol. 14, no. 3, pp. 248-251, 1995.
[16] D. J. Spurgeon, M. A. Tomlin, and S. P. Hopkin, "Influence of temperature on the toxicity of zinc to the earthworm Eisenia fetida," Bulletin of Environmental Contamination and Toxicology, vol. 58, no. 2, pp. 283-290, 1997.

[17] A. Ostrowska, S. Gawlinski, and Z. Szczubialka, Methods of Analysis and Evaluation of the Soil and Plants Properties, Instytut Ochrony Srodowiska, Warsaw, Poland, 1991 (Polish).

[18] OECD (Organization for the Economic Cooperation and Development), Guidelines for the Testing of Chemicals, Earthworm Acute Toxicity Tests no 207, Original Adoption, 1984.

[19] V. J. G. Houba, T. M. Lexmond, I. Novozamsky, and J. J. van der Lee, "State of the art and future developments in soil analysis for bioavailability assessment," Science of the Total Environment, vol. 178, pp. 21-28, 1996.

[20] I. Barrera, P. Andrés, and J. M. Alcañiz, "Sewage sludge application on soil: effects on two earthworm species," Water, Air, and Soil Pollution, vol. 129, no. 1-4, pp. 319-332, 2001.

[21] P. Scaps, C. Grelle, and M. Descamps, "Cadmium and lead accumulation in the earthworm Eisenia fetida (Savigny) and its impact on cholinesterase and metabolic pathway enzyme activity," Comparative Biochemistry and Physiology C, vol. 116, no. 3, pp. 233-238, 1997.

[22] C. Dauberschmidt, D. R. Dietrich, and C. Schlatter, "Esterases in the zebra mussel Dreissena polymorpha: activities, inhibition, and binding to organophosphates," Aquatic Toxicology, vol. 37, no. 4, pp. 295-305, 1997.

[23] H. Aebi, "Catalase in vitro," Methods in Enzymology, vol. 105, pp. 121-126, 1984.

[24] S. J. Yu, "Host plant induction of glutathione S-transferase in the fall armyworm," Pesticide Biochemistry and Physiology, vol. 18, no. 1, pp. 101-106, 1982.

[25] M. M. Bradford, "A rapid and sensitive method for the quantitation of microgram quantities of protein utilizing the principle of protein dye binding," Analytical Biochemistry, vol. 72, no. 1-2, pp. 248-254, 1976.

[26] F. Leduc, J. K. Whalen, and G. I. Sunahara, "Growth and reproduction of the earthworm Eisenia fetida after exposure to leachate from wood preservatives," Ecotoxicology and Environmental Safety, vol. 69, no. 2, pp. 219-226, 2008.

[27] T. Jager, S. A. Reinecke, and A. J. Reinecke, "Using process-based modelling to analyse earthworm life cycles," Soil Biology and Biochemistry, vol. 38, no. 1, pp. 1-6, 2006.

[28] T. Phipps, S. L. Tank, J. Wirtz et al., "Essentiality of nickel and homeostatic mechanisms for its regulation in terrestrial organisms," Environmental Reviews, vol. 10, no. 4, pp. 209-261, 2002.

[29] E. F. Neuhauser, Z. V. Cukic, M. R. Malecki, R. C. Loehr, and P. R. Durkin, "Bioconcentration and biokinetics of heavy metals in the earthworm," Environmental Pollution, vol. 89, no. 3, pp. 293-301, 1995.

[30] M. Saint-Denis, J. F. Narbonne, C. Arnaud, and D. Ribera, "Biochemical responses of the earthworm Eisenia fetida andrei exposed to contaminated artificial soil: effects of lead acetate," Soil Biology and Biochemistry, vol. 33, no. 3, pp. 395-404, 2001.

[31] S. Panda and S. K. Sahu, "Recovery of acetylcholine esterase activity of Drawida willsi (Oligochaeta) following application of three pesticides to soil," Chemosphere, vol. 55, no. 2, pp. 283-290, 2004.

[32] M. J. Jonker, A. M. Piskiewicz, N. Ivorra i Castellá, and J. E. Kammenga, "Toxicity of binary mixtures of cadmium-copper and carbendazim-copper to the nematode Caenorhabditis elegans," Environmental Toxicology and Chemistry, vol. 23, no. 6, pp. 1529-1537, 2004. 
[33] Y. Y. Mosleh, S. Paris-Palacios, M. Couderchet, S. BiagiantiRisbourg, and G. Vernet, "Effects of the herbicide isoproturon on metallothioneins, growth, and antioxidative defenses in the aquatic worm Tubifex tubifex (Oligochaeta, Tubificidae)," Ecotoxicology, vol. 14, no. 5, pp. 559-571, 2005.

[34] P. K. Hankard, C. Svendsen, J. Wright et al., "Biological assessment of contaminated land using earthworm biomarkers in support of chemical analysis," Science of the Total Environment, vol. 330, no. 1-3, pp. 9-20, 2004.

[35] S. Jänsch, G. K. Frampton, J. Römbke, P. J. van den Brink, and J. J. Scott-Fordsmand, "Effects of pesticides on soil invertebrates in model ecosystem and field studies: a review and comparison with laboratory toxicity data," Environmental Toxicology and Chemistry, vol. 25, no. 9, pp. 2490-2501, 2006.

[36] M. J. Jonker, R. A. J. C. Sweijen, and J. E. Kammenga, “Toxicity of simple mixtures to the nematode Caenorhabditis elegans in relation to soil sorption," Environmental Toxicology and Chemistry, vol. 23, no. 2, pp. 480-488, 2004.

[37] G. K. Frampton, S. Jänsch, J. J. Scott-Fordsmand, J. Römbke, and P. J. van den Brink, "Effects of pesticides on soil invertebrates in laboratory studies: a review and analysis using species sensitivity distributions," Environmental Toxicology and Chemistry, vol. 25, no. 9, pp. 2480-2489, 2006.

[38] C. Pelosi, S. Barot, Y. Capowiez, M. Hedde, and F. Vandenbulcke, "Pesticides and earthworms. A review," Agronomy for Sustainable Development, 2013.

[39] S. Yasmin and D. D'Souza, "Effects of pesticides on the growth and reproduction of earthworm: a review," Applied and Environmental Soil Science, vol. 2010, Article ID 678360, 9 pages, 2010.

[40] A. Zawisza-Raszka and B. Dolezych, "Acetylcholinesterase, catalase and glutathione S-transferase activity in beet armyworm (Spodoptera exigua) exposed to nickel and/or diazinon," Acta Biologica Hungarica, vol. 59, no. 1, pp. 31-45, 2008.

[41] A. Zawisza-Raszka, B. Dolezych, S. Dolezych, P. Migula, and M. Ligaszewski, "Effects of nickel exposure and acute pesticide intoxication on acetylcholinesterase, catalase and glutathione Stransferase activity and glucose absorption in the digestive tract of Helix aspersa (Pulmonata, Helicidae)," International Journal of Environment and Pollution, vol. 40, no. 4, pp. 380-390, 2010. 

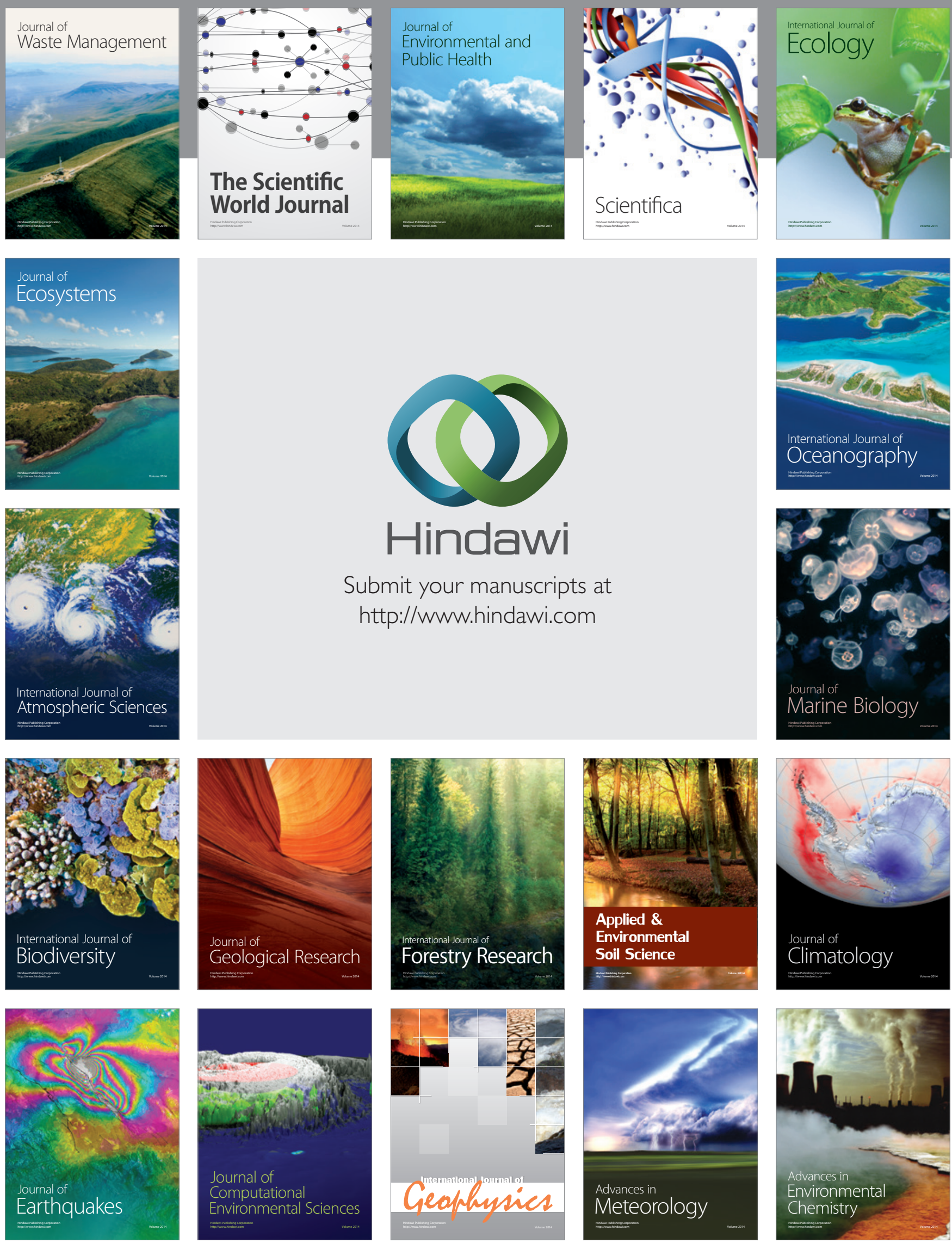